\title{
HOW OLD IS RUNOSONG? DATING THE MOTIFS OF BURIAL-RELATED FOLK SONGS BY USING ARCHAEOLOGICAL MATERIAL
}

\author{
Pikne Kama
}

\begin{abstract}
The aim of this article is to compare Estonian burial-related runosongs (regilaul) to archaeological information. I introduce the runosong as a potential source of information about burials to archaeologists and give folklorists a new perspective by addressing the age and practises behind the motifs of runosongs. One runosong may contain elements from different time periods, and for this reason I have concentrated on dating the elements of storylines. However, I have also tried to match the idea of a whole song-type with one or another time period. The five biggest analysed song-types are as follows: "Daughter on her mother's grave", "Mother and loves", "The burial of a boy and a girl", "Open graves", and "A coffin made of stones", altogether 1654 songs. Two of them, "Daughter on her mother's grave", and "A coffin made of stones", consist of a considerable amount of prehistoric elements (from the Iron Age, before 1225), which should prove the prehistoric origin of these song-types. Especially notable is the description of the land of the dead, rooted in prehistory, still preserved in songs collected in the nineteenth and twentieth centuries. At the same time, the overall amount of prehistoric elements in the whole corpus is small, and most of the datable elements refer to historical burial customs.
\end{abstract}

Keywords: afterlife, archaeology and folklore, death culture, Estonian burial customs, runosong

\section{INTRODUCTION}

How old are the songs constructed in a special way, called runosongs (known also as runic songs, regilaul or Kalevala-metric poetry), traditionally sung among the Baltic Finns? It has been claimed that some storylines are "really old" or even "ancient" (Tedre 1998: 549). As archaeologists' main interest is past human culture, it would be great to use runosongs, in addition to archaeological information, to get a better understanding about the past. At the same time, it is hard to use material considered to be old or ancient without more precise dates. So, first of all, when studying runosongs from an archaeological perspective, the main question is how old these songs are. 
There are two different aspects to be dated in runosongs. The first question is: When did people start to sing this way, meaning, how old is the form of the runosong? Another and quite different question is how old is the content of the runosong. The manner of singing is said to have evolved more than 2000 years ago, as a result of an interaction between the Baltic Finns and the Proto-Balts (Tedre 1998: 548) or from the beginning of the first millennium AD (Merilai 2006: 16). Although such attempts to date the form of the runosong are interesting, they do not tell us which time period the runosong describes. The present study focuses on the second question; namely, how old are the motifs of the runosong.

Lines of the runosong contain descriptions of past material and intangible culture (e.g. beliefs, emotions, rituals). Archaeologists study the past material culture, and the archaeological material could be the best way to place lines of the runosong in the original context and, by doing so, we can date the motifs of the songs.

There have been previous attempts to date some individual elements of the runosong. Maybe the most famous is Lennart Meri's interpretation that the motif 'Saaremaa on fire' is a reflection of the fall of the Kaali meteorite on the island of Saaremaa (Meri 2008: 115-123). Kaali meteorite craters are dated to 1530-1450 BC (Losiak et al. 2016), which would mean that these lines of the runosong originate from the Early Bronze Age. Some folklorists have used archaeological material in the interpretation of the runosong (e.g. Arukask 2011), and archaeologists have found the lines of the runosong helpful in understanding the belief system behind archaeological finds (e.g. Valk 1992: 139; 2004: 272-273). Using runosongs and other folklore material definitely gives more possibilities for the interpretation of archaeological record.

\section{CURRENT APPROACH TOWARDS THE RUNOSONG}

Although the elements of the runosong have been dated previously, my research provides a systematic analysis of one theme in runosongs - burials. In comparison with some previous studies, I have explored more material than just selected interesting examples and my data is not limited to one song-type only; therefore I hope to present a more general understanding about the age of the content of burial-related runosongs.

I have analysed runosongs describing burials or the situation that follows (revisiting graves by relatives). This topic was chosen for dating because there is a considerable amount of archaeological information about burial customs (compared to other past practices). Graves can be considered as the most thoroughly examined type of prehistoric relics (Jonuks 2005: 43). Death culture 
has changed remarkably in time, which makes it easier to connect motifs of songs with one or another time period. The biggest change in burial customs about which we have more record was caused by the Livonian Crusades in the thirteenth century, which in Estonia is also the borderline between prehistory and historical times. In this article, by prehistoric elements I mean elements from the Estonian Late Iron Age (550-1225 AD). Archaeologists have a good knowledge of cremation burials in stone graves from the Late Iron Age. However, upon Christianisation, old burial places were in most cases abandoned and the majority of society had inhumation burials (Valk 2001: 87-88; Mägi 2003: 91).

My approach may at first seem strange to archaeologists, as they usually use material culture to make assumptions about intangible culture (e.g. religion). In my study, I may use intangible culture (runosongs) to make assumptions about material culture. This may certainly be problematic because all details in poetic texts need not be expressed or be visible in material culture. But we encounter the same problem when interpreting archaeological data because the scale of meanings of archaeological finds also varies in intangible culture. For example, every ornament did not necessarily symbolise something and its purpose could have been only decorative (Wilson 2001: 47). In most cases I do not use runosongs for making assumptions about material culture, but try to connect material and intangible culture. The main question is whether these connections are reasonable. The study focuses on two aspects. Firstly, it describes the characteristic motifs of five major burial-related runosong types. Secondly, the study contains interpretations of these motifs and their connections to archaeological data. The first part, the description of the content of the songs, is quite reliable. The interpretative part is definitely more subjective, and there is room for future reinterpretations. It aims at addressing songs on the basis of past practises that are mostly visible in archaeological records; other possible ways of interpretation are not in the focus of the study.

Runosongs are said to be like Lego because they are constructed by using different building blocks (Lintrop 2001: 299-300). These elements or building pieces can originate from different time periods. Dating one element does not mean that a song as a whole is from that time period. It is logical that songs, when passed on orally from one generation to another, have been modified. Each element in a song is important to support an idea or a storyline of the song (Arukask 2000: 66). So, when passing on the storyline, the singer could have used new elements to express older ideas (or, conversely, the singer could have used older song lines to construct new storylines). Therefore the study focuses on dating the motifs combined into the runosong. At the same time I try to connect the overall idea of a song-type with the worldview or the social context of one or another time period. Also, one might assume that a considerable number of older elements testify to the older origin of the song-type. 
Runosongs have their characteristic form, which distinguishes them from other folk songs. I will shortly introduce three main poetic features of these songs. They use alliteration (words in one line start with the same initial sound; see, e.g., Lehiste \& Ross 2001: 13). This can affect also the content of the runosong - some words may have been used because they fitted in with alliteration and not because they were the best choices to express the overall idea of the song. At the same time this factor has made the runosong conservative as it is difficult to change words in song-lines. The second characteristic element is parallelism, which means that successive lines repeat the same or a similar meaning (ibid.: 14). The third structural principle is that runosongs are in specific trochaic metre, known as the Estonian version of Kalevala-metre (Sarv 2015). The examples of runosong lines in this article are translated by the author. In order to render the exact meaning of the song-lines, I have not used formal poetic features in the translations.

The studied songs were collected mostly at the end of the nineteenth or the beginning of the twentieth century, when the tradition itself was slowly dying out. My study area is limited to Estonia, but the runosong tradition spread also among other Baltic Finns, except for the Livs and Vepsians (Tedre 1998: 548). As a rule, the Estonian runosong tradition reflects society from the perspective of a peasant woman (Tedre 1998: 554-555). As runosongs were created in community-centred culture, in the process of communication, we may argue that they do not express rare or individual habits and beliefs. Still, runosong lines describe diverse understandings or opinions, and the texts express cultural diversity. The runosong has preserved parallel elements from different ages, which may explain the diversity in the songs. When runosongs were collected, the original singing situation was usually not registered. There are some notes accompanying the texts, and it is also possible to make some assumptions based on their content. According to the limited records, some studied songtypes were sung during burial rites or when visiting graves (Fig. 1). However, there are also notes about singing them in other situations, such as swinging, working, or when putting a child to sleep. It is unknown whether in the more distant past these songs were sung in everyday life situations, or whether these notes reflect the fading of runosong culture, when songs could have lost their traditional function and meaning.

This article is largely based on my earlier studies (Kama 2010, 2012) but, in addition, some new material has been reviewed. I have studied all the burialrelated runosong texts in Estonia that I have found. ${ }^{1}$ The choice of the elements that I kept track of when examining songs is somewhat subjective. It was mainly affected by the construction of the songs themselves; at the same time my focus was on the elements which could be compared with archaeological material. 


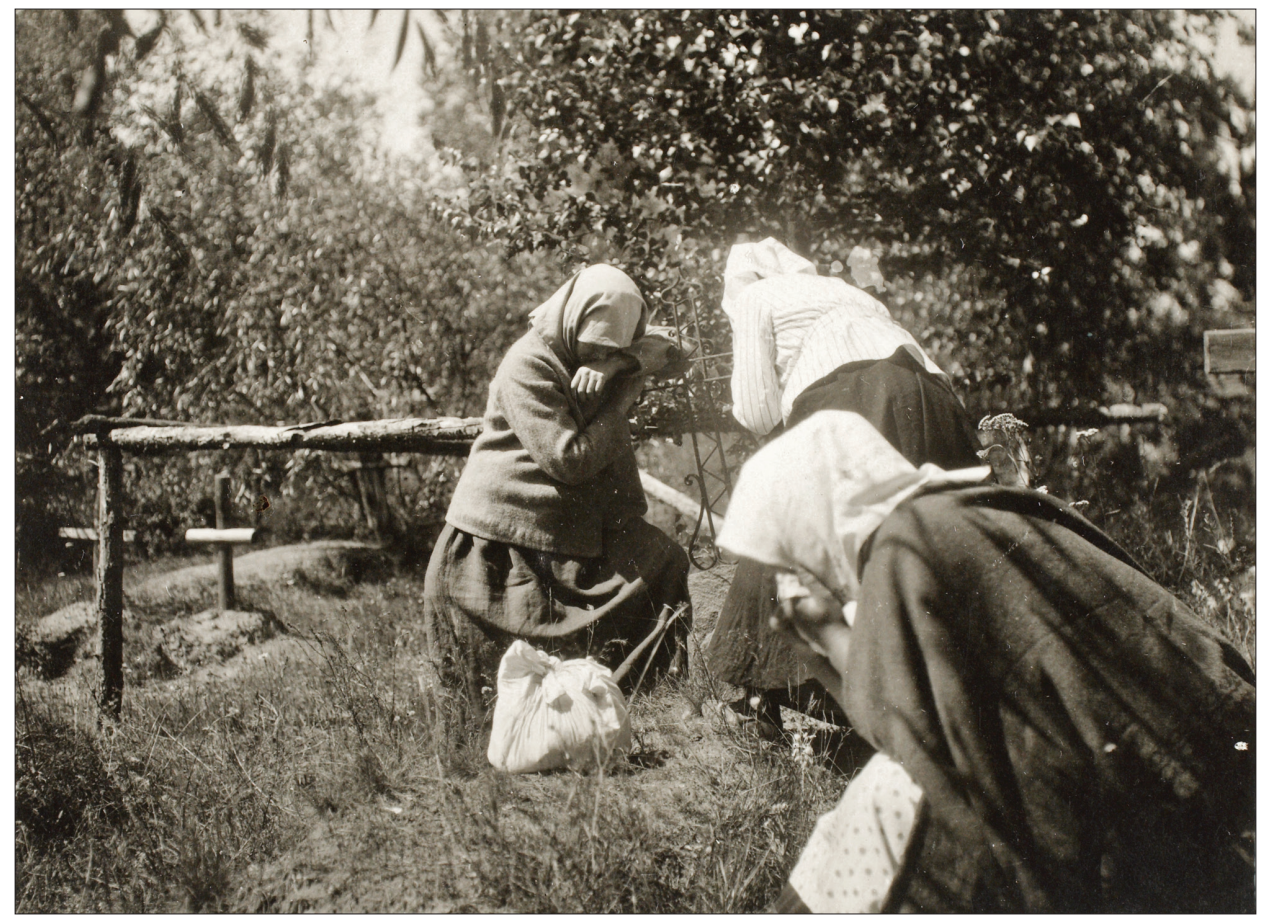

Figure 1. Visiting graves after burials was when burial-related songs were sung. Illustrative picture of women lamenting a dead person in Obinitsa graveyard. Photograph by Armas Otto Väisanen 1922 (ERM Fk 350:214).

Next I am going to introduce and analyse five biggest burial-related types of the runosong, bring out characteristic elements, and try to match these with actual burial traditions. I also give approximate time periods when a song-type may have emerged. The most numerous song-type is "Daughter on her mother's grave" (1001 songs), followed by "Mother and loves" (200), "The burial of a boy and a girl" (181), "Open graves" (143), and "A coffin made of stones" (129). ${ }^{2}$ All of these song-types have spread across Estonia. Also, there are 21 minor songtypes about burials, which altogether consist of 110 songs. I am not going to introduce and analyse the minor song-types, but sometimes I use their elements in comparison with the major song-types. 


\section{THE SONG-TYPE "MOTHER AND LOVES"}

The main element that distinguishes the song-type "Mother and loves" (Ema ja armud) is the description of the movement of the dead person's love/mercy, mostly used in the plural form. I use the word 'loves' in translation, which is questionable because the meaning of the word armud is uncertain in the songs. In contemporary Estonian the word arm is not used in plural form.

The song-type describes how a dead person (usually a mother) is taken from home to the cemetery and how her 'loves' move with her. They travel together with the mother's body, but their routes are different. The 'loves' can go through a window, beneath a fence, and along treetops, but when they reach the cemetery, they are buried with the deceased: ${ }^{3}$

Imä ära koolenessa; armu ära lõpenessa.

Imä viidi lävesta; armu pajasta pagesi.

Imä viidi värjist;

armu lasti laidist.

Ima viidi teeda mööda; armu lasti laanta mööda.

Imä hauda kaivanessä; arm ol'l haua veere pääl.

Ima hauda pandenessa; armu ala lammenessa.
Mother died; loves ended.

Mother was taken over the sill; loves escaped from the window. Mother was taken from the gate; loves were made to go from the top. Mother was taken along the road; loves were made to go along the forest. Mother's grave was dug; love was on the edge of the grave. Mother was put in the grave; loves lay beneath.

J. Wäggi from Vana-Piigaste municipality, Kanepi Parish, 1891 (H III $11,474(7))$

A dead body is handled by others and the actions are described with the words 'taken', 'put', 'carried'. At the same time the 'loves' move independently and their actions are highly varied. 'Loves' can, for example, 'step', 'run', 'beg', 'cry', 'fall', 'fly', even 'march' or 'wrestle'. Probably their specific actions are not so significant, but the overall idea of these song-lines is the opposition of a passive body and the active 'loves'.

The simplest interpretation of this storyline and 'loves' is that it is a poetic depiction of how the loss of a parent meant also the end of her or his love and care for the child. This interpretation is supported by the songs in which 'loves' in parallel song-lines correspond to the mother's warm words. At the same time 
there are cases where 'loves' have been described as connected with the singer's own burial or a child burial:

Latsel hauda kaivettii; arm ümber kareli.

Last hauda panti; arm ala lamõsi.
A child's grave was dug; the love hopped around. The child was put into the grave; the love lay beneath.

(EÜS X 893 (88))

It shows that everybody can have 'loves', and hints that 'loves' once may have had a more complex meaning than just parent's love.

The ability of 'loves' to fit into small places, move through small openings, or fly seems to be coherent with what are traditionally thought to be characteristic elements of a non-material soul. In my interpretation 'loves' are soul-like beings. The plural form could express the idea about the plurality of souls. Examples of the belief system in which humans have more than one soul are known among many northern Eurasian indigenous peoples (Paulson 1958), and signs of the plurality are also evident in Estonian folklore (Loorits 1990 [1948]: 33). The plurality of a soul is rooted in prehistoric religion, but regrettably this possibility has been used only in the interpretation of the belief system of the Estonian Stone Age (Kulmar 1992a, 1992b, 1992c). Although most of the songs use 'loves' in the plural, these beings act in the same way. Also the movement of the 'loves' is closely connected with the course of the deceased body and in the end they are all buried with the dead. This may mean that when this song-type was formed, the concept of multiple souls had lost its independence and was in the middle of transformation into the concept of a single soul.

\section{THE SONG-TYPE “OPEN GRAVES"}

The burial-related song-type "Open graves" (Avanenud hauad) describes how an orphan goes to play with a round object and it rolls to a graveyard. The round object breaks the 'doors' of a grave and the orphan sees his or her dead relatives doing handicraft inside. When asked for whom they are making these things, the dead family members claim that they are intended for his or her because he or she was left without care as a child. These songs reflect the belief that the dead can have an impact on this world and may help the living: 
Läks tema kurni kukutama;

hõbe õuna veeretama.

Kurn kukkus kiriku aeda;

hõbe õuna haua peale.

Haua uksed lahti läksid;

haua uksed, kalmu kaaned.

Nägin oma memmekesta.

Memme kangast ju kuduvat;

hõbe lõnga lõksutavat;

kuldi niisi nikutavat.

Mina mõistsin, kohe kostsin:

"Hellakene, memmekene.

Kell sa kangast ju kujuksid?”

"Sull ikka, sull ikka, tütar noor

Sa jäid helmita elama;

kaelarahata kasuma."
She went to drop the skittles;

to roll a silver apple.

The skittles fell into the churchyard;

the silver apple on the grave.

The grave doors opened;

the grave doors, mound caps.

I saw my mom.

Mom was weaving a fabric;

a silver yarn popped;

a golden thread was picked.

I understood, asked straight away:

'Dear mother.

For whom are you weaving the fabric?'

$i$.'For you, for you, young daughter.

You had to live without beads;

grew up without neck coins.'

M. Saar and H. Siimer from Anna Liiver, 59. Village of Maalaste, Pilistvere Parish, 1907 (EÜS IV 1652/3 (132))

Playing with a round object is characteristic of most of the songs. Usually, the round object is skittles or, in parallel lines, a 'silver apple'. The play of skittles is a traditional Estonian game, where skittles (round wooden blocks) were knocked down by throwing sticks (Kalamees 2007: 38), although song-lines may derive from some other traditional game involving a round object (Annus \& Sarv 2015). On the basis of these songs it is possible to claim that the play of skittles could have had a ritual meaning and may have been performed purposely in order to establish contact with the dead (Lintrop 2001: 306). Children's folklore (including games) has preserved many activities that once had a ritual or magical meaning (Vissel 2004: 37). Unfortunately, there might not be any archaeological records about rituals that took place on the grave after burials. Clay balls that have been interpreted as gaming pieces have been found from the Reinberg rural cemetery in Järve village (Virumaa County) in connection with seventeenth-century burials (Schmiedehelm 1946a: 13, 30-34; 1946b: 16). The actions described in songs may give us some hints about why these toys were found there.

In the song-type "Open graves", the churchyard is a popular burial place (in $~ 76 \%$ of the songs) where an orphan meets his or her dead relatives. 'Grave doors' are often mentioned, which may refer to a coffin lid or a gate of a burial chamber. However, burial chambers were not used by Estonian peasants, who 
were the singers of these songs. Grave doors could be a symbol of an overall idea that the grave is a house for the dead (a grave as a house is also mentioned in the song-type "Daughter on her mother's grave"; see below). Grave doors may be a symbolic border between the worlds of the living and the dead, and by breaking them the orphan can see and communicate with his or her relatives.

The activities of the dead in graves are described in about $73 \%$ of the songs. The most popular ones are the song-lines representing a dead mother or sister making clothes; a dead father or brother is usually doing some woodwork. Also, sometimes counting and making coins or doing metalwork in the grave is mentioned. The making of clothes and woodwork seems to be, in most cases, connected with the preparation of a dowry. This shows that these songs were probably sung during wedding rituals as it has been described in the case of the song-type "Daughter on her mother's grave" (see below).

Also, archaeological finds reflect the belief in working in one's afterlife as tools were popular grave goods in the past. It is most reasonable to connect these song-lines with less distant burial practices from the Middle Ages and the Early Modern Age. Small tools, such as knives, needles, and thimbles were popular grave goods, and even spindle whorls, axes, and drawknives have been found in graves (Valk 1992: 129, 133-136). The belief system behind these finds has already been previously illustrated by the song-type "Open graves" (ibid.: 139). The archaeological material from historical times does not provide evidence about the belief in metalworking in graves, and the closest rare examples of smith's tools from graves date back to the eleventh-twelfth centuries (e.g. Lavi 1999: 49-51). Activities with coins described in songs could be connected with the real coin finds from cemeteries. Coins were the most common grave goods in historical times (Valk 2001: 76), but rather rare in prehistoric graves, where they were used mainly as jewellery in necklaces. In the Middle Ages and the Early Modern Age, coins were manufactured in local towns (Leimus 1996: $50,69-74)$, which seems to reflect the description of hammering and sawing the coins in songs. It is known from the nineteenth and twentieth centuries that one of the reasons why coin offerings occur in burial rites is because they brought luck or money for those who were left behind (Valk 1992: 150). These explanations seem similar to the song-lines in which money is counted or made for a living relative.

A few descriptions of dead parents sitting on a chair in graves are exceptional:

Messe esa havvan teie?

Esa iste tooli pääla;

ema tooli veere pääla.

(H III 10, 109/10 (16))
What was father doing in the grave?

Father was sitting on a chair; mother on the edge of the chair. 
This may be connected with a real body placement during burials. One burial in the sitting position was found at Kuremäe barrow-cemetery which dates to the twelfth-thirteenth centuries (Ligi 1993: 31), but there are also some notes in archives describing skeletons in the sitting or standing position, which have been found accidentally (Valk 1992: 76-77). The tradition of placing a dead body in a sitting position used to be more widespread among the Votes on the Izhorian plateau in the twelfth-thirteenth centuries, and was occasionally practised up to the beginning of the fifteenth century (Valk 1992: 76-77 and the sources cited therein).

An interesting element in songs is the description of the clothing of the dead. Among these are the rare song-lines about colourful burial clothes:

Mis sääl hauas nähtanessa?

Isa üsna uusi kuube;

ema lillene liinikas;

sõsara sõba sinine;

venda kullane kübara.
What was seen in the grave?

Father's quite new coat;

mother's flowery doily;

sister had a blue shawl;

brother a golden hat/helmet ${ }^{4}$.

(EKS 8¹, 232/4 (21))

Colourful burial clothes were used until the mid-fifteenth century when they were replaced by clothes of mainly white colour (Valk 1992: 123). The songlines describing the clothes of a dead person as golden or tinsel may reflect the tradition of decorating textiles with bronze spirals or tin studs. Decorations of bronze spirals have mainly been found from the Final Iron Age inhumation burials, but in some cases from the burial context up to the fifteenth-sixteenth centuries (Rammo 2005: 18). In the fourteenth-fifteenth centuries, the tradition of decorating clothes with bronze spirals started to fade and tin decorations became dominant (Värv 2008: 280). In the sixteenth century linen textiles started to be commonly used for grave clothes (Valk 1992: 123; Rammo 2014), which probably gives the time boundary for frequently mentioned linen garments.

\section{THE SONG-TYPE “A COFFIN MADE OF STONES”}

The song-type "A coffin made of stones" (Kivine kirst) differs from other songtypes as it represents the singer's wishes connected with his or her own burial. The most important wish is to have a special coffin (in $96 \%$ of the songs). Wood as the most common coffin material in real life is not suitable. The singer asks for a coffin made of stones (68 mentions) or tin (48 mentions). The most desir- 
able materials for different details of a coffin are bone (59 mentions) or copper (40 mentions).

Kui mina ükskord ära suren. When I once die.

Ärge mul tehke kuusest kerstu; Don't make me a coffin of spruce;

kuust on kuri kõmmeldama. $\quad$ spruce is evil to bend.

Ärge mul tehke männast kerstu; Don't make me a coffin of pine;

mänd on kuri mädanema. pine is evil to rot.

...

Tehke mulle kivist kerstu;

kivist kerstu rauda risti.

Make me a coffin of stones;

Hundi luusta lukud ette; a stone coffin, an iron cross.

karu luusta kaaned pääle; Locks in the front from wolf bones; põdra luusta põõnad pääle. caps on the top from bear bones;

Ärge mind viige vankeriga. belts on the top from elk bones.

Vanker oli kuri vapustama. Don't take me by cart.

Ärge mind viige reega.

Regi oli kuri viitama.

A cart is evil to shake.

Don't take me by sledge.

Viige mind viie sõrmega;

A sledge is evil to drift.

kandke mind kahe käega.

Take me by five fingers;

carry me with two hands.

G. J. Treumann from Harju-Madise Parish, 1876 (H I 4, 164 (7))

Based on archaeological record, pine and spruce were the most common materials for coffins in historical times (e.g. Valk 1992: 105; Tiirmaa 1997: 73), but in songs these are among the most despised types of wood. It seems that the expected burials are not traditional for common people, but the singer's wishes reflect the burial customs of the elite. The wish for a coffin made of stones is probably connected with the tradition of stone plates on graves, stone sarcophagi, or burial chambers. If one does not interpret the word 'coffin' directly, this wish may originate from the prehistoric stone grave tradition. The situation in the Final Iron Age, when the pagan tradition of stone graves and inhumation burials in wooden coffins competed with each other, may explain why wood is regarded as the opposite of stone. It must be kept in mind that stone graves were also burial places for selected members of society (Lang 2011). The changing burial traditions of the elite due to the spread of Christianity and in later times also affected the expected burial in songs. Roughly half of the songs mention a church or a chapel and the wish for a special cross. Also, the popular request for a coffin made of tin seems to be a more recent element added in historical times. Although the burial customs of the elite had changed 
considerably, stone remained a prestigious material, which has helped to preserve the older song-lines.

The lines about the desire to have coffin details from the bones of wild animals also seem to belong to the older layer of elements. The most popular bones were those of elk, roe ${ }^{5}$, wolf, and bear. Some bear calf finds from stone graves (e.g. Maldre 2003: 272) have served as evidence for the interpretation that a dead person could have been cremated in a bear fur shroud (Jonuks 2009: 281). This custom may have inspired these song-lines. Wild animals were also part of the elite lifestyle in the Middle Ages, when hunting and eating wild animal meat was a privilege of the higher social class (Mänd 2004: 298).

In ten songs there is a wish not to be left on the ground for birds to eat or not to be buried under the ground for worms to eat. The singers ask to be taken to a church or a cellar, which is likely connected with the tradition of grave chambers built for the nobility. But some songs also mention Viru vitsik as a desired destination. It is not fully clear what is meant by this phrase (vitsik means 'bushes'), but this is more likely a name for a burial place in nature. It must be mentioned that also cremation burials in stone graves seem to be coherent with the plea not to be left on the ground and not to be buried; burning a body precludes eating it and stone graves are not underground; nor are human remains left in the open air.

There is a request in five songs that a hole be left in the coffin, so that wind, smells, or the soul could move:

Vellekene, noorekene.

Kui läät auda kaivamaie.

Jätä pilu päävä poole;

akan ao tõsengude.

Õimu tulla,

õimu minnä;

sugu võsal suu anda.
Brother, young.

If you go to dig a grave.

Leave a slit towards the sun;

a window for the dawn rise.

For the kin to come;

for the kin to go;

kindred to kiss.

(H II 28, 311/2 (11))

This wish may also correspond with the stone graves, where there are natural holes between stones. The other possibility is that the song-lines are about the tradition that has not left any archaeological record. Some analogy could be found in the Ob-Ugric burial tradition, where symbolic houses were built on the grave (which may have contained the remains of a dead body) with holes or windows (Ksenofontov 1988: 338-340). These holes are opened when relatives come to the grave so that the soul of the dead can join the ritual meal in the graveyard (ibid.: 340). Similar grave structures are also known much closer to 
Estonia, in the area of the runosong tradition. In Karelian burial places there have been similar buildings on graves with holes or windows made in the side of the sunrise (Kemppinen 1981: 268). This is similar to the song-lines mentioning that a hole in the grave should be towards the sunrise. One possibility is that these lines may have been transferred within the runosong culture, and some Estonian song-lines may represent Karelian burial customs. At the same time, it is more likely that the tradition of buildings on graves with holes may once have been more widespread among the Baltic Finns, and these song-lines do represent local or regional burial customs.

About $38 \%$ of the songs mention a wish not to be taken to a burial place in a vehicle but rather to be carried there. This kind of action may reflect the situation up to the beginning of the eighteenth century when burial places were often near homes. Another possibility is to connect these lines with private burial places of landowners near their mansions. Songs scorn taking the deceased to the cemetery by brougham or carriage (which was used by the elite) and therefore these song-lines do not seem to reflect the lifestyle of landowners.

\section{THE SONG-TYPE "THE BURIAL OF A BOY AND A GIRL"}

The song-type "The burial of a boy and a girl" (Poisi ja neiu matus) describes the boy's dishonourable burial as opposed to the girl's prestigious burial. Unlike other song-types, this seems to have been a mocking song. The burial place of a boy is most often a swamp (89 mentions) or a forest ( 82 mentions), but a girl is usually buried in a nice churchyard (124 mentions). The mourners of a boy are often wild animals, such as a wolf (95 mentions) or a bear (88 mentions). At the same time the girl's mourners constitute the elite of the society: for example, lords, landowners, kings. Some songs also mention the girl's family members as mourners. On the boy's grave such unpleasant plants as nettles or thistles grow; by contrast, different flowers usually grow on the girl's grave.

Kui see poissi sureksida.

Kes on teda saatemassa?

Siga on teda saatemassa;

emised on ehitamas;

vana kult on kuulamassa.

Kus see poissi maetakse?

Soosse, porimaasse;

vanaraba mättaasse.

Mis kasvab poisi haua peala?
When this boy dies.

Who will accompany him?

A pig will accompany him; sows will prepare the attire;

a boar is watching.

Where will this boy be buried?

In a swamp, muddy ground;

in an old bog tussock.

What is growing on the boy's grave? 
Mõned harvad angervaksad; vanad nurjatud nõeksed.

Kui see neidu sureksida.

Kes on teda saatemassa?

Saksad teda saatemassa;

emandad on ehitamas;

kuningad on kuulamassa.

Kus see neidu maetakse?

Kirikusse, kirratusse;

kabelisse, karratusse.

Mis kasvab neiu haua peale?

Angervaksad, hallid topid;

sinililled, siidi topid;

kullerkupud, kulla topid.
Some rare dropwort;

old wicked nettles.

When this girl dies.

Who will accompany her?

Lords will accompany her;

ladies will prepare the attire;

kings are watching.

Where will this girl be buried?

In a church, colourful;

in a chapel, tinselly.

What will be growing on the girl's grave?

Dropwort, grey wisps;

liverleaves, silken wisps;

globeflowers, golden wisps.

H. Siimer and W. Rosenstrauch from Luise Mumme, 35. Village of Rohu, Simuna Parish, 1908 (EÜS V 950/1 (217))

Probably the most interesting element for archaeologists is the frequent mentioning of mire as the burial place for a boy. The first reference that comes to one's mind is the famous bog bodies in northern and north-western Europe. Nearly 1800 bodies have been found from the bogs in Denmark, England, Sweden, Ireland, Norway, etc. (Parker Pearson 2008 [1999]: 67). What is more, sometimes the song-lines describe wood around the body:

Kui nee peiju koolenesse.

Kohes neid matetas?

Suurte suo mätta hala.

Mis neile ümbre pandas?

Ragask hala, ragask pääle.
When those grooms will die.

Where will they be buried?

In a big swamp, under a tussock.

What will they put around them?

Logs down, logs on top.

(H II 51, 316 (6))

This seems to match the archaeological record where bog bodies have been found with wood, which is used to drown a body or is placed there for protective magic (Wessman 2009: 88). However, because the song-lines and finds of bog bodies are generally separated by a huge difference in time and space, I would not make a direct connection between them. However, there is an example which may give some evidence about practices behind the song-lines. One archaeologically documented mummified body, dated to the end of the seventeenth or to the beginning of the eighteenth century, has been found in a bog in Estonia (Jonuks \& Oras 2012: 21-22). The Rabivere bog body was found by peat diggers and the position and good condition of the deceased woman's body indicate that 
the woman had not drowned but had been buried into the peat (ibid.). Songs may indicate that such finds are more common, and it could well be that we may not have found the other bog bodies in Estonia yet. Also, a seventeenthcentury written source mentions the regulation that people who do not go to church or take part in communion cannot be buried in the churchyard, and their bodies have to be thrown into swamps (Kahk 1980: 676). The songs from south-eastern Estonia mention that the burial place of both the boy and the girl is a mire, which shows that mire is not only a metaphor for a negative burial place. In a minor song-type, "A silent burial place" (Vaikne matusepaik), the singer's own wish is to be buried in a bog:

Viige mind raba kaldasse.

Kus ma ei kuule kukke häält; vie venna laulamist;

ei kahe õe karjumist.
Take me into the edge of a bog.

Where I cannot hear the rooster crow; singing of five brothers;

no screams of two sisters.

$$
\text { (H, R 1, } 206 \text { (2)) }
$$

Another popular burial site for a boy is the forest. This may refer to the prehistoric burial places that after falling into disuse could be regarded as belonging to the wild sphere of nature. In rare cases prehistoric graves were used also in historical times (Jonuks 2009: 272), which shows that people were aware of their existence and used them in specific situations. Another possibility is that the lines refer to rural cemeteries of historical times. Rural cemeteries were probably covered with trees (Valk 2001: 23), and the use thereof could be seen as burying into a forest.

A girl's burial place was in most cases connected to a church or a churchyard. It must be kept in mind that the archaeological record does not show any significant difference between the number of women and men buried in churchyards. A church is often described as golden and silvery, which could be a description of Catholic-period churches before the Lutheran period since the late sixteenth or the early seventeenth centuries. This song-type shows that at least one part of the society admired Christian Germanic culture of the elite. It was sometimes even stated that a girl was buried under an altar which is the most sacred burial place in churches.

\section{THE SONG-TYPE “DAUGHTER ON HER MOTHER'S GRAVE”}

This popular song-type describes how orphans go to the graves of their dead parents and ask them to wake up and help them. Mother and father answer that different things keep them in the grave-most commonly plants and trees 
have grown on the grave, the soil covers their bodies, or they smell of death. The orphan promises to perform different actions to remove these obstacles, such as to cut down the grass and trees, dig up the grave, or wash off the smell of death. Usually dead parents still cannot awake and give the child advice to seek help from living people or from the heavenly forces. Although this song-type is named "Daughter on her mother's grave" (Ema haual), visiting the graves of both one's mother and father is common. The most general wish is that the deceased could help with the preparation of a wedding chest. The question of an acceptable dowry may have been very important to orphans. There are short notes indicating that these songs have been sung during weddings or that a bride has sung it on her mother's grave (S 11189/90 (25); ERA II 159, 667/8 (67); H II 32, 82/4 (72)).

Õli kaksi vaesta lasta. Menid Jaanipää keriku. Nuttu rättikud käessa; nuttu kirjad rättikussa. Tõine pühkis tõise silmi.

Nü̈̈d läksid ema haua pääle "Tõise üles emakene; tõise vakka valmistama; ja siis sukki sooritama; kirstu kaantta kinnitama." ...

"Ei sa tulla tüttar noori. Silmil on sinine liiva; kulmul on kulu punane; jalul on jalaka metsa; pea pääl on pärna metsa. Too siula siulu liiva; too kirves raiju metsa. Siis tulen vakka valmistama; kirstu kaandta kinnitama."
There were two orphans.

Went to church on Midsummer's Day.

Crying kerchiefs in hands; crying patterns in the kerchief.

Wiping each other's eyes.

...

Now they went to the mother's grave:

'Rise up mother; rise to make the wedding chest; rise to prepare the stockings; to close the chest lid.'

...

'Can't come, daughter young. On my eyes is blue sand; on my brow is hay red; on my legs is elm forest; on top of my head is a lime-tree forest. Bring a sieve, sift the sand; bring an axe, chop the forest. Then I will come to make a dowry; to close the chest lid.'

Marie Treuberg from Leena Selli. Kurtna municipality, Vaivara Parish, 1891 (H II 37, 67/8 (1))

While most of the songs end with the dead staying in the grave, there are also cases where the situation remains unresolved or the dead parents promise to rise (as in the previous example). Two songs even depict what could happen if the dead actually woke up: 
Viiksin koiduksi kojuje;

ämarikusi äraje.

Kole on kojugi viia;

jäle on järile panna;

ile pinki istutada.

Kuhu pian pallaka panema;

ihulise istutama?

Paljaks taab palju maada;

ihuline ilma ruumi.

Panen parsile magama;

sialt ta kohe kukutelle;

üle kaela üpitelle.

Ja saab otsa ometigi.
Would bring home for dawn;

in duskiness away.

Horrific even to bring home;

disgusting to put on a bench;

terrifying to plant onto a stool.

Where will I put the naked body;

plant the flesh?

Naked needs lots of ground;

flesh needs a world of space.

Put it to sleep on the perch;

from there it fell right down;

over the neck hopped.

And dies nevertheless.

(H I 1, 74 (38))

In about $40 \%$ of the songs a church or a chapel is named in connection with visiting a grave. Church mostly occurs in descriptions of visiting one's parents' grave on Midsummer's Day. This is coherent with ethnographical notes describing that Midsummer's Day has been a very important holiday of the deceased (Hiiemäe 1985: 37-40). One song can mention a church, but at the same time there are descriptions of a forest or stones on a grave, which does not fit in with the appearance of a churchyard. This shows again that a song can reveal coexisting heterogeneous elements from different time periods. Although the songs do not specify what kind of burial site they describe in archaeological terms, there are some interesting details. For example, the songs of south-eastern Estonia mention the "white sand hill", which reminds of the appearance of round barrows:

Karjah käväh lö̈̈se ma.

Kos ole imä mattõdu.

Valgõ liiva mäe sisse;

halja haina mättä ala.

(H III 30, 827/8 (5))
During herding I found.

Where mother is buried.

In a white sand hill;

under a green hay sod.

Round barrows from the Final Iron Age were occasionally used in the eastern part of south-eastern Estonia (Valk 1992: 38), and their distribution area seems to generally match the spread of the motif of the 'white sand hill'. It is hard to say whether these lines originally reflected the round barrow tradition because medieval and post-medieval rural cemeteries were also often situated on sandy hills. At least churchyards can be excluded as these lines describe a burial place near one's home in nature because an orphan finds it when herding.

The north-eastern Estonian songs describe a grave as a house: 


$\begin{array}{ll}\text { Läksin eide aua pääle; } & \text { Went to mother's grave; } \\ \text { auduja südämä pääle; } & \text { to the hatcher's heart; } \\ \text { tuojani tua laele; } & \text { on the carrier's room's ceiling; } \\ \text { kandajani katusselle. } & \text { on the bearer's roof. }\end{array}$

(H II 1, 606 (784))

The view of the burial place as a house is probably an old belief, and many types of prehistoric burial structures have been interpreted as symbolic or real houses (see, e.g., Vassar 1943: 160; Mägi 2004). In the songs an orphan goes onto the roof of a grave and therefore it seems that these song-lines rather describe a symbolic house. It is possible that also traditional earth graves could have been seen as houses of the dead.

In most of the songs parents cannot rise due to plants that have grown on the grave. Descriptions of blue hepaticas growing on the eyes and golden globeflowers on the eyebrows of the dead are frequent. Also, a blue forest, blue soil or blue sand, and red hay or red flowers occur in the same context than hepaticas and globeflowers. It shows that it was important to express the blue and red or golden colour in connection with the eyes of the dead. It is difficult to specify what these colours symbolize in this context, but in general 'blue' and 'red' are characteristic of the descriptions of liminal situations (e.g. giving birth, weddings, death) in the runosong tradition (Jaago 1997). The most common action against the plants growing on a grave was feeding them to domestic animals, mainly cattle. Bringing a herd to a burial place was frequent in the songs, but also cutting hay with a scythe was mentioned. Grazing a burial place does not seem to reflect actions possible in a churchyard, which was usually far away from home and surrounded by a stone wall. These lines most likely describe rural cemeteries, which date to the thirteenth-eighteenth centuries (Valk 2001: 87-90); however, the prehistoric background of this element cannot be excluded either.

Sometimes it is mentioned that herbs growing on a grave give power to animals:

Lase aga mullikad murule; härjad aru heinamaale; lehmad sinililledele. Mullikad murul tugevad; aru heinal härjad suured; sinilillel lehmad lajad.

(H I 2, 695/6 (33))
Let heifers on the grass; oxen to the fescue meadow; cows on liverleaves. Heifers are strong on the grass; on the fescue hay are oxen big; on liverleaves are cows broad. 
This is one way how the dead can actually help the living. At the same time some songs describe an opposite situation, in which grass from a grave draws life force from animals. These two elements may show different attitudes towards herding in burial places. In some areas or even inside one community, not all people may have approved it. However, it seems more acceptable to use a burial place for herding. In many songs trees grow on graves. Songs describe cutting down the trees, shooting animals and birds in trees, and two songs even mention ploughing in a burial place. These actions were probably not common in burial sites, but the song-lines express anger against the obstacles that hold the parents in graves. At the same time song-lines probably show that behaviour in burial places has not been so limited, for example, in comparison with natural holy places where even breaking off a branch was strictly forbidden (see Kütt 2007: 187-200).

A common reason why the dead cannot leave the grave is because they have a bad smell:

Mul om jo man maa hais; suu man surma hais; käte man kääpä hais; muijal kõik mulla hais.
I have with me the earth smell; near my mouth the death smell; on hands the mound smell; everywhere else the soil smell.

(H II 45, 266/7 (9))

An orphan promises to bring a special soap or lye to the grave or heat a special sauna where the parent's body would be washed:

Viin siis kondid vihtlemaie;

sooja sauna suitsumaie.

Andma viha virdeella; paistma päikse paisteella.

Siis mulle kasvab kaunis ema; armuline isa naene.
Then I will carry your bones to whisking with birch twigs; into a warm sauna to smoke. Give some whisking water; show in the sun glow.

Then will grow me a beautiful mother; gracious father's wife.

(Leoke 1, 79/82 (4))

It must be mentioned that in traditional burials the body of the deceased was kept in the sauna before funerals and always washed. By performing these actions again, an orphan may have hoped to reverse the rituals and therewith also the death. This element is hard to date, but the smell of death seems to be related to inhumation burials where the body of the dead started to rot. At the same time only bones could be the subject of washing (like in the previous example), and the origin of the motif can be connected with multi-staged burials in prehistory. 
Bringing a sieve to the grave was often mentioned. In most cases it was used to sift the grave soil in order to awake the dead parent. Some descriptions are rather intriguing:

Oleks mullast võtemine;

kirikusta kiskumine;

hauasta arutamine.

Tooks linnast liiva sõela; alevista arva sõela.

Miska sõeluksin sõmera.
If there was taking from the ground; tearing from a church; ripping up from the grave.

I would bring a sieve from town; from hamlet a large sieve.

With this I would sift through the soil.

(H II 9, 178/9 (13))

The ethnographic records show that the sieve had a special meaning: it has been used for healing, predicting the future, and in other magical activities (Valk 2004: 253-271), which may explain why a sieve is frequently mentioned in songs. The sieve was significant already in the Iron Age as there are pendants symbolizing the sieve, mainly found in burials (ibid.: 234-250). Heiki Valk has suggested that sieves may have been used in different stages of cremation burial rituals, mainly for collecting cremated bones by sifting through the remains of a pyre (ibid.: 273). The runosong lines may give indirect evidence for this hypothesis as it is sometimes mentioned that the sieve is fiery, red-hot, or grimy, which may refer to cremation burial. In songs sifting through the remains of the dead could again be performed to reverse death. In the minor song-type "Good girl dead" (Hä̈̈ neiu surnud) sifting through a funeral place is mentioned in most of the songs with the purpose of getting hold of the bones of the deceased:

Soklu läbi linna liiva;

kae läbi kalmu liiva.

Ehk saad näta näiu luida;

näda näiu sõrme luida;

kaia neiu kaala luida.
Sift through the town sand;

look through the grave sand.

Maybe you can see the girl's bones;

see the girl's finger bones;

see the girl's neck bones.

(EÜS XII 1291 (55))

It is hard to guess whether those song-lines refer to real manipulation of the remains of the dead. There is no record of such manipulation from historical times and in the case of prehistoric cremation burials it is really hard to say if the burned bones were touched after placing them into the burial place. However, there are some examples of Final Iron Age inhumation burials where graves have been reopened and the position of bones modified (Jonuks 2009: 276-277 and the sources therein). These actions are usually interpreted as the result of grave robbery or baptism of the dead (ibid.). Runosongs provide a new 
interpretation of the disturbed graves. It is possible that, in order to establish the closest connection to the dead, the remains of the dead were examined, touched, or used.

Keeping in mind archaeological record about prehistoric burial customs, I followed the mentions of fire that could indicate cremation burials. The cremation tradition did not fully end at the beginning of historical times (Valk 1993), and it is possible that not all the cases in the runosong originate from the prehistoric period. The runosong does not reveal any direct descriptions of cremation burials, but there are a few examples where cremation may explain the song-lines. Most interesting are the following lines:

Tuli nakkas mul peäle tulema; Fire started to come on me; palav nakkas mulle peäle paistma; heat started to shine on me; kibena peale karatellema. $\quad$ sparks started to hop on me.

Külmaoleslännukalmukabukene. I would have gone to the grave, maiden. Vasta mul kahetsi kalmulise; Stared back at me the deceased; vasta mul kahetsi ilmulise. Seda ei ole kalmun kasunu; seda om ilma istotu.

Kohe istotu elava. stared back at me the earthly beings. This has not grown in the grave; this is planted on the earth. Where the living are planted.

(H II 62, 675/6, 719 (29))

One might think that the description of fire in this song-text is a poetic description of the hard life of the orphan. For me, the detailed description of the person catching fire, after which she could go to grave, opens the way for a more intriguing explanation. It may be that the orphan tries to reach the otherworld through fire, which may be consistent with cremation burials, in which the dead disappeared through fire and moved to the afterlife. In south-eastern Estonian songs an orphan asks the parents to rise from the oven's fire, which may also indicate that in case the dead parents disappeared into the fire, they can also reappear from it. Fire is mentioned also on the way to and in the land of the dead (see below).

The descriptions of stones in connection with the dead could indicate the prehistoric stone grave tradition. Although burials with stones did not come to an end with prehistory (see, e.g., Valk 1992: 64-69), a stone construction on graves was untypical in historical times. Stones on the grave were mentioned in 85 songs (5.6\% of total). More than one stone or even a stone heap was mentioned in 56 songs. A single stone on the grave may refer to the tradition of placing a bigger stone in the grave filling. This custom was recorded in Siksälä cemetery from the thirteenth-fifteenth centuries (one burial was also dated to the eighteenth century) and is interpreted as prevention against the 
dead returning home as revenants (Laul \& Valk 2007: 41). This interpretation fits in with the songs in which a stone is the reason why the dead cannot rise. Descriptions of more than one stone in a burial site seem to reflect the appearance of stone graves quite well, for example:

Paas on all ja paas on pial; Limestone is beneath and limestone is above; mina paade vahela; I am between the limestone; kivi rink mull rinde pial. a stone heap on my chest.

(H IV 2, 516/8 (2))

or

Eite pandi haudajani. Mother was put into the grave.

Armud jäid haua kaldasse. Loves were left on the grave bank.

Seal on armu lapsekestel. There is love for children.

Kivi ääres tuule varju;

kivi varede vahela. Nearby a stone are their shelters from thewind;

Tunnikeseks tuule varju; between stone heaps.

päevakeseks päeva armu. for a day love from the sun.

(EÜS VII 1594/5 (114))

Actually, it is logical that there are almost no descriptions of cremation burials in this song-type; yet many descriptions of stone graves. This song-type does not usually describe funeral practices but rather the situation after burial. What is more, the stones support the overall storyline as they constitute an obstacle that keeps the dead in the grave.

There are two songs in which the stones are said to be an orphan's dowry. Stone graves are believed to have marked the ownership of land (e.g. Lang 1996: 510-512), and therefore the original meaning of these song-lines may have been that although the orphan's parents are dead, their family still own the land where their burial place is situated.

The songs describe also coffins and crosses. Unlike fire and stones, the mentioning of these refers to burial customs of later periods. Although coffins were used already in the Final Iron Age (see, e.g., Selirand 1974: 80), it was probably not until the seventeenth century that burying in coffins evolved into a common practice among peasants (Valk 1992: 103). A cross can be yet another reason why a parent cannot wake. It is not known when the cross became widespread as a grave mark. Coffins are mentioned in 5.6\% of songs and crosses in $9 \%$ of songs. Some songs describe an iron cross on a grave, which peasants started to use at the end of the eighteenth century (Kõuts \& Valk 1998: 10). Thus, the iron cross is one of the latest datable elements in songs. 


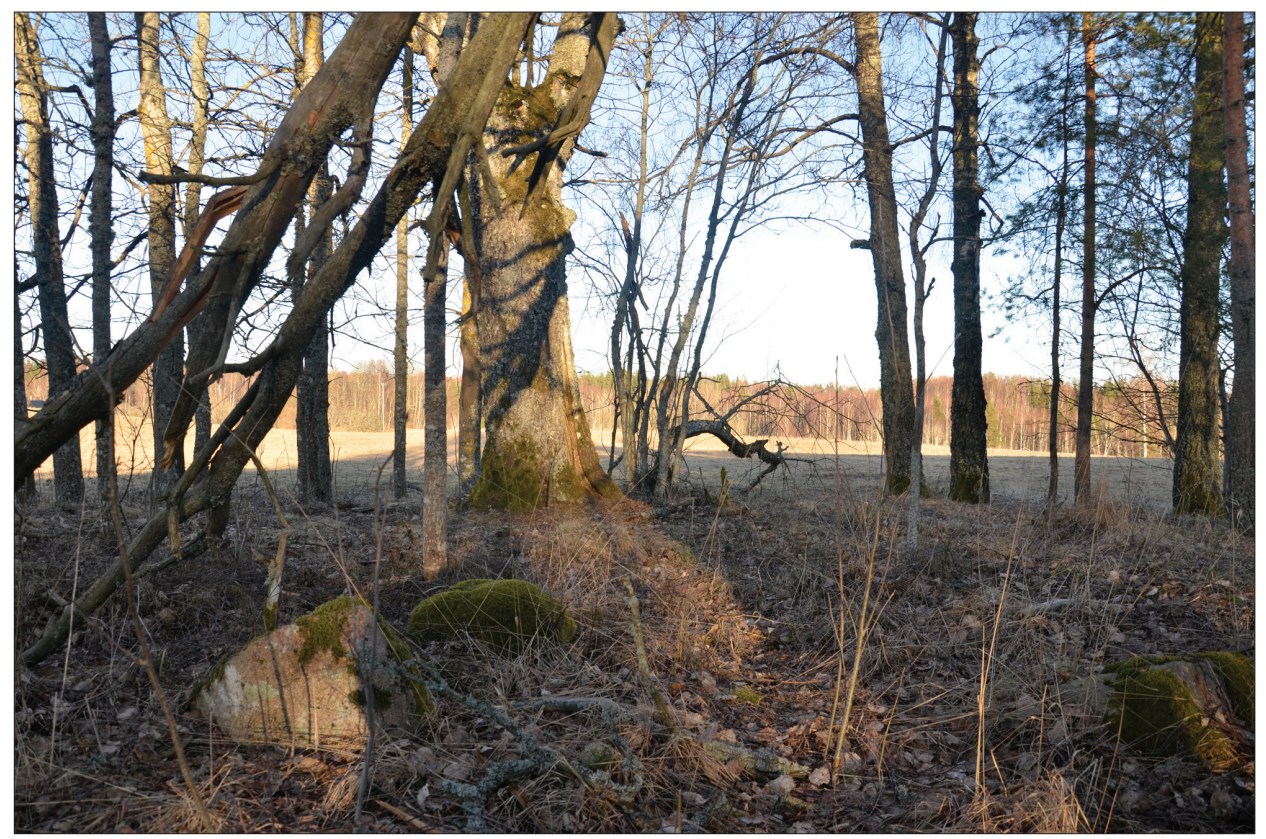

Figure 2. Contemporary appearance of a stone grave with stones and trees in Karula Parish. Illustrative photograph by Pikne Kama 2014.

In the song-type "Daughter on her mother's grave" the dead are usually in their graves; they can communicate, but otherwise their activities are quite limited. Some songs depict the dead as more active, for example:

Ema vaat varemelta; sinilillede seasta.

Tüdard noorda naidetes.
Mother was looking out from the ruins; amongst liverleaves. How her young daughter was getting married.

(H II 24, 460/2 (247))

In rare songs parents can return home as a bug or a bird:

Kodo tiä õks lindas liblikah; kodo tiä ôks kä̈̈ kärbläseh. Miä um ôks tuvi tulba otsah; haugas tare harä pääl?

Tuu um õks mino imäkane; kabu um õks kats vanembad.

(H II 32, 226/7 (2))
Home she flew as a butterfly; home she is going as a fly. Why is a dove on the stake; why is a hawk on the crest? This is my mother; two parents of the maiden. 
or:

Kui ei mahu maista tulla. If you cannot come from the ground.

Tule luike lunta mööda; $\quad$ Come as a swan on the snow;

tule kajakas kivisid mööda; $\quad$ come as a seagull over stones;

vesi lindu vetta mööda. as a water bird along water.

(E, A 740/1)

This image is similar to folktales where human souls can leave their bodies in the shape of a bug, and in Setumaa, south-eastern Estonia, there is a belief about a soul butterfly who leaves the body after death (Loorits 1990 [1948]: 36-38). A few songs describe an orphan who has to look for her parents at home because they are hidden somewhere on the farm. It remains unclear whether it refers to a parent's soul or the psychical remains.

The song-type mentions different deities or mythical beings. When dead parents cannot help an orphan, they sometimes advise them to seek help from heavenly forces. The songs often mention jumal (God), but also Mari / Maarja (St. Mary), or looja (Creator). When singers used such words as 'god' or 'creator' within the time period when songs were collected, they probably meant the Christian God. In earlier times the word jumal denoted a prehistoric deity (see Vainik 2014) and these song-lines may not originally refer to the Christian God.

Mythical beings appear in a situation different than heavenly forces as they may constitute another obstacle that prevents the dead from awaking. Tooni/ Toonis are often mentioned in some areas:

Ei ma lää, tütarlaits.

Mul om kolmi hoitijata.

Tooni poiga pähitsella;

Tooni tütar jalutsella;

vana Tooni keskeella.
I cannot go, daughter.

I have three holders.

Tooni's son on my head;

Tooni's daughter on my feet;

old Tooni in the middle.

(H II 44, 513/5 (19))

Also, some songs mention Tooni's wives:

Ei või minna tütarenni;

ei või astu armas latsi.

Vasta kaitsva kalmu naise;

tõrõlõsõ Tooninaise.

"Mis sa maine maalõ astud;

kabo käüma kääbäjille?”

(H, Mapp 621 (40))
Cannot go to the daughter; cannot step, dear child.

Against are the protecting mound wives; scolding Tooni's wives:

'Why do you, earthly, step on the ground; maiden, walking to the grave?' 
The Toonis (old Tooni, Tooni's son, Tooni's daughter, Tooni's wives) are connected with the prehistoric land of the dead called Toonela, and their field of activity is connected with death, which distinguishes them from the forces of heaven. In historical Tartumaa and Mulgimaa, instead of the Toonis, Mary's rooster and the Creator's hound are mentioned:

Mul o manna katsi vahki; katsi vahki, kolmi vahki. Looja hurda jalutsinna; Maarja kikas päetsinna. Johus jalga liiguteme.

Looja hurta haugateme. Johus pääda liiguteme. Maarja kikas kiuksateme.
I have with me two guards; two guards, three guards. Creator's hound on my feet; Mary's rooster on my head. Happen to move my leg. Creator's hound barks. Happen to move my head. Mary's rooster crows.

(EÜS V 312/5 (10))

One can agree with Aado Lintrop who claims that Mary's rooster and Creator's hound took over the position of the Toonis in songs (Lintrop 2001: 307). It would be interesting to know when this replacement occurred. While the mentioning of Maarja (St. Mary) may refer to the Middle Ages, a dog in the context of the guardian of the dead can be older. Dog burials have been found in western Estonian stone graves dating to the Viking Age (Jonuks 2006: 32-34). The interpretation of this widespread tradition argues that dogs used to be the guardians of the otherworld in European mythology, although a similar interpretation of Estonian dog burials has been considered implausible (ibid.: 40, and the sources therein). However, at least in this Estonian song-type, dogs seem to have a meaning similar to that in European mythology. Whenever Mary's rooster and Creator's hound took the place of the Toonis, both alternative versions have been preserved in songs.

In 38 songs ( $3.8 \%$ of the songs) the land of the dead was mentioned. Most often it was named as Toonela or House of Tooni, but also Iiela, Manala, House of Maraliste, Hell, and once also the Creator's chamber. It is remarkable that the songs did not mention that the dead parents would be in Heaven or in Paradise. Ülo Valk has suggested that the overall idea of the song-type that the dead could rise comes from Christianity where resurrection of the flesh is possible (Valk 2000: 259-260). Aado Lintrop has shown how a similar idea is expressed in songs of unbaptised Finno-Ugric peoples (Lintrop 2001: 301). Connecting the origin of the idea with Christianity in songs seems unlikely also to me as the described afterlife reveals very few Christian aspects. For example, Heaven, Purgatory, the devil, or angels are not mentioned in connection with the dead. 
Hell occurs in parallel lines with Toonela, and it seems that because of Christianity, the previous otherworld was equalized with Hell. In reality an orphan probably did not believe that the loved parent would be in Hell. ${ }^{6}$ Toonela, Iiela, Manala, and the House of Maraliste probably originate from the prehistoric belief system. It is difficult to say if these names have marked different lands of the dead or they are synonymous. It seems more likely that in prehistory there may have existed more than one land of the dead and in runosongs these have survived only as names. Iiela seems to connect with the word hiis, which is a popular name for natural sacred places; also, mythical beings living in these sites are called iied (see: Loorits 1990 [1948]: 67-69).

Only Toonela is described in greater detail. It is situated somewhere above, far away, or is equalized with a burial place. On the way to see a dead parent, fire and water are mentioned:

Läbi lä̈̈se ma eädse jõe; $\quad$ I would cross an icy river;

läbi tulitse tungelde; go through fiery torches;

üle lääse ma sõru uiboost. cross a burnt field of apple-trees.

Oles saasi ma nättä imä armo; If I could feel mother's love; kaija imä kassumist. witness mother growing up.

(H, Jagomann 276/9 (13))

Fire and water are also depicted in Toonela:

Tooni tuli on turbeline; $\quad$ Tooni's fire is soddy;

kalmu vesi verine. mound water bloody.

(H II 62, 671, 718/9 (26))

Afterlife in Toonela is similar to life in this world: usually mother and father are responsible for farm work, for example, scything, sweeping, ploughing, or taking care of Tooni's animals. Probably the tools found in the graves reflect the same belief of working in Toonela. Some songs express anger against Toonela:

Olõs ma tiidünü Tooni tarõ; $\quad$ If I had known the House of Tooni; vai kül Tooni tarõ läve. or even the threshold of the House of Tooni.

Ma olõs kirvõ kätte võtnu; I would have taken an axe in my hands; käsikabla kainladõ. a rope under my armpit.

Üles ma olõs lännü nulka müüdä; I would have gone along a corner; maha saanu saina müüdä. got down along a wall.

Maha olõs tõukanu Tooni ussõ; I would have pushed down Tooni’s doors; põrutõnu põrgu värjä. banged at the hell's gates. 
Ussõ ma iks toonu uma imä; I I would have brought out my mother; uma kalli kasvataija. my dear mother who brought me up.

(H II 32, 61/3 (45))

These descriptions may not show the usual attitude towards the land of the dead as in songs it constitutes another obstacle that prevents the dead from rising.

\section{DISCUSSION}

Although comparing the runosong with archaeological data is definitely an interesting task, there are also many difficulties that have to be kept in mind. First of all, the archaeological material is fragmentary and has a tendency to become even more fragmentary when moving back in time. Only a part of the past material culture has survived until today, and archaeologists have studied but a small amount of it. As was noted above, archaeological material about burials is abundant and it is one of the most extensively studied topics in archaeology. Nevertheless, Valter Lang has pointed out that we know how only about $20 \%$ of people were buried in Estonia in the Final Iron Age (Lang 2011: 112). When looking for older elements in burial-related runosongs, there is no reason to think that the older elements reflect only the customs of those $20 \%$ of people whose burial customs are familiar to us. For example, the minor song-type "Birds will bury" (Linnud matavad) describes how a dead body is eaten by birds. Leaving a deceased body on the ground will most likely not leave behind any archaeological traces. If we do not have any archaeological material, it is more difficult to find traces of these actions also in runosongs. For example, if there had not been any knowledge of the tradition of the stone graves, their descriptions in songs would probably have been overlooked. At the same time, when the archaeological material (maybe also with the help of runosongs) becomes less fragmentary, the gap between different sources about the past should become smaller.

Moreover, runosongs are not ethnographical descriptions; some customs have not been mentioned in songs at all, but some details may be described in many parallel lines. For example, in south-eastern Estonia there is a tradition of cutting a cross on a tree on the way to the graveyard, which was more widespread in the past (Torp-Kõivupuu 2003: 103-105). Although the song-type "Mother and loves" describes how a dead person is taken from home to the cemetery, the tradition of cutting a cross on a tree is not mentioned. Another example is the ritual eating on graves that is believed to have been common in the past all 
over Estonia (Valk 1992: 158), but is uncommon in Estonian runosongs. The custom of taking food to the grave is mentioned only in the minor song-type "Not afraid of death" (Ei karda surma). Thus, on the basis of non-occurrence of elements it is hard to draw conclusions about the real behaviour in the past.

I have presented different percentages in my analysis to illustrate the occurrence of elements and variability between the song-types. At the same time, the meaning of these numbers calls for interpretation. For example, the possible description of stone graves occurred in 5.6\%, and the prehistoric land of the dead was mentioned in $3 \%$ of the songs belonging to the type "Daughter on her mother's grave". These numbers do not mean that $3-5.6 \%$ of elements in the runosong are of prehistoric origin. It is clear that in some areas songs contain older elements than in others. One song may reveal elements from different time periods, but generally older elements occur together. Songs that belong to the same song-type but contain elements from different time periods prove once again how the motifs may have been modernized, but the overall idea or the storyline has survived.

If there had been runosong lines describing the tradition of inhumation burials in the Final Iron Age, these elements would probably have had a much bigger chance to be preserved when inhumation burials became widespread. Henry's Chronicle of Livonia describes how in the thirteenth century Estonians practised cremation burials with traditional wailing and drinking (HCL 2003: XII, 6). It is reasonable to think that the described wailing is the singing of burial-related folk songs and the songs they sang may have described cremation burials. However, when the cremation burial tradition died out, the lines or even the song-types may have also vanished. It is possible that when the burial rites changed, the song-lines that did not make sense anymore were reframed and understood as poetic expressions that preserved some of these relics in later periods. In reality, only those elements of the runosong are datable that describe the part of culture that has changed over time. The song-lines describing more static things (e.g. death of a parent, emotions involved, description of nature) were relevant and understandable during longer time periods - there was no need to change these. It means that the overall age of the song elements may be older than shown in the present study.

The runosong lines about intangible culture seem to be more stable as they were not so strictly connected with behavioural culture. On the basis of runosongs one might claim that prehistoric deities and beliefs about afterlife lasted long after Christianisation by comparison with the prehistoric burial traditions, which usually faded rather quickly. It is also important for archaeologists to bear in mind that there might be a gap between practices and beliefs. For example, 


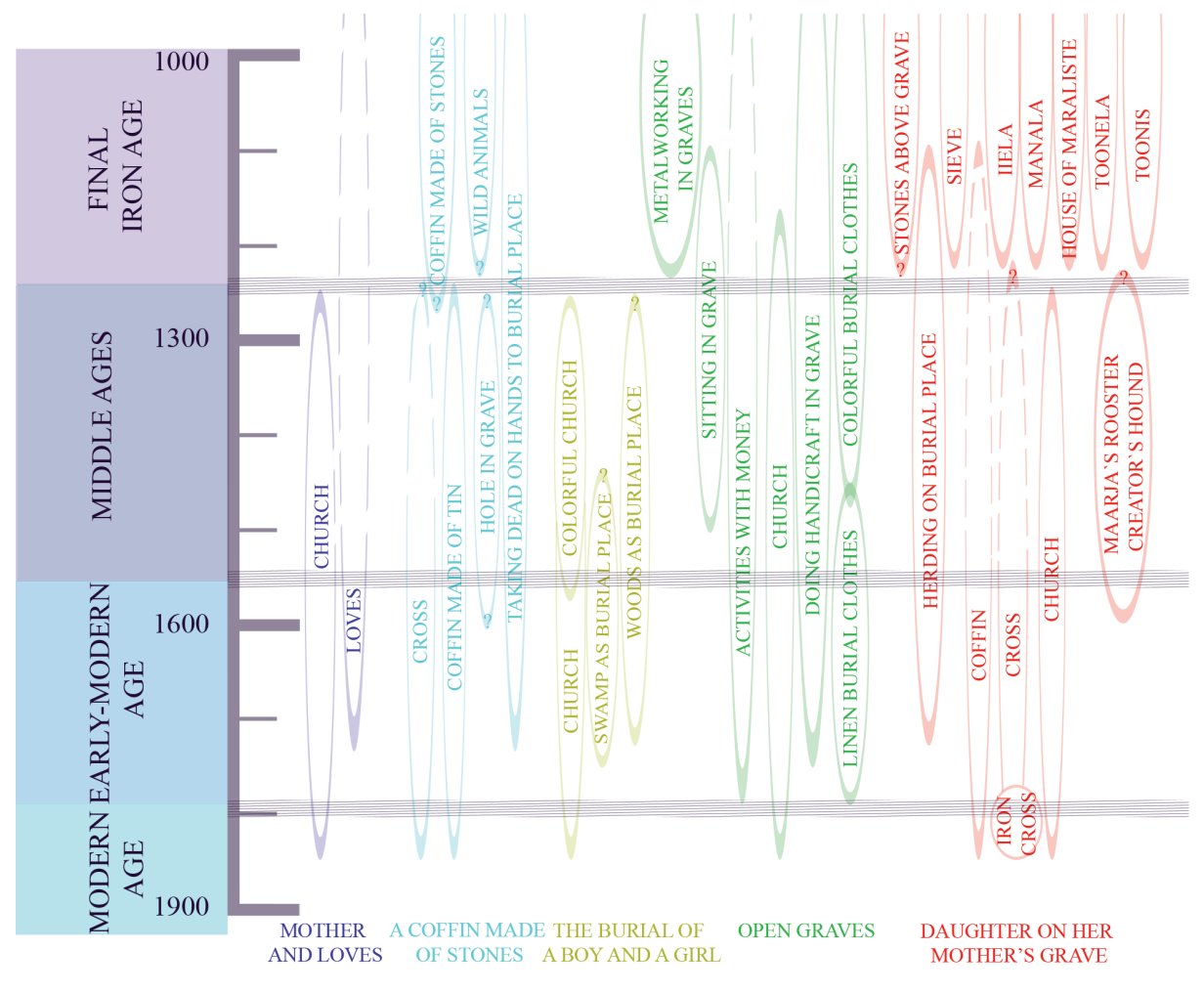

Figure 3. Analysed motifs of burial-related runosongs and the possible temporal context of their origin.

when studying burials from the Middle Ages, in which the dead were buried according to Christian tradition, we might find that the belief system behind the burials does not reflect Christianity.

The present analysis shows considerable variation in the age of elements in the song-types (Fig. 3). Different song-types seem to have been formed in different time periods. The overall storyline in the song-type "Mother and loves" is rather short, with only few datable elements. The mentions of a coffin, graveyard, or church seem to reflect traditional burials in Estonian peasant society. As these songs spread all over Estonia, the song-type could have emerged before the Great Northern War (1700-1721) or maybe in the seventeenth century, when the fight against pagan beliefs was active and the understanding that a human being had many souls could have started to disappear. It seems most 
likely that the song-type "Open graves" emerged in the Middle Ages (due to frequent mentioning of church and the dead doing handicraft in graves), but as the song-type contains elements from many time periods, it is hard to say something for certain. The song-type "A coffin made of stones" could be rooted in prehistory, when inhumation burials with coffins in earth graves competed with the stone grave tradition. The main idea of the song-type "The burial of a boy and a girl" is to contrast positive and negative burials: boys' burials in songs are probably affected by pagan traditions and those of girls describe the desired Christian burials. One possibility is that this song-type evolved in the seventeenth century when the Lutheran Church fought actively against pagan traditions. A few older elements may refer to an older age of this songtype, suggesting it might have emerged at the beginning of the Middle Ages when old burial places were abandoned and Christianity became widespread among common people. It may also be that the older elements or stereotypical lines were taken over from other runosongs because the general atmosphere in the song-type under discussion seems to fit mainly with the situation in the seventeenth century. The notable occurrence of prehistoric elements in the song-type "Daughter on her mother's grave" should prove its origin in the Late Iron Age, but, like other song-types, it has been strongly influenced by burial customs of later periods.

These song-types represent a variety of ideas that may have coexisted in the past; also, these concepts may originate from different time periods and may have coexisted only in the runosong tradition. Based on the decrease of grave goods during historical times, Heiki Valk suggested that the end of prehistory witnessed the beginning of a process when the dead became passive and unsociable (Valk 1992: 167-170). Beliefs about afterlife became blurred and the activities of the dead became more and more limited (ibid.). Runosongs may support Heiki Valk's hypothesis. The understanding that parents work in the land of the dead comes from prehistory. In the Middle Ages the belief about the otherworld could have started to disappear and people may have believed that the dead were staying in their graves, where they practised handicraft as expressed in the song-type "Open graves". The time period featuring the disappearance of grave goods could be reflected in the song lines in "Daughter on her mother's grave", where the dead cannot move or help the living. Some songs say that the dead cannot even communicate with the living, which is the main motif of this song-type. The Christian understanding that the dead could be in Heaven is not expressed in the songs that I have analysed, although this understanding is widespread in other folk beliefs related to burial and afterlife (see, e.g., Valk 1992: 148-150) and also in some other types of the runosong. 
I believe that on a wider scale Heiki Valk's generalization is true, but the actual situation has been more complicated. For example, descriptions of the prehistoric deities, Toonis, who held the dead in their graves, show that the activities of the dead could probably have been quite limited already in the Late Iron Age. Nor is it clear how to connect the belief with the described process that a dead person can come home as a bug or a bird.

Finally, as the age of the elements in burial-related song-types varies considerably, the present study does not allow us to make a generalization about the age of other motifs of runosongs, which have not been similarly analysed. A similar study should give more answers about other groups of runosongs, but at the same time it may be hard to find archaeological or other information for comparison.

\section{CONCLUSION}

There is no simple answer to the question of how old the motifs of the runosong are. The analysis of burial-related songs showed that they combine elements possible to date to the end of the eighteenth century and extending back at least to the Final Iron Age. As numerous variations of the song-types showed, the elements could have been updated due to the changes in the surrounding culture, but the idea of songs has been more stable. A conservative dating of the storylines of major song-types shows that at least two of these may have a prehistoric background ("Daughter on her mother's grave" and "A coffin made of stones"), although these have been greatly affected by the traditions of historical times. The other three song-types seem to originate from the belief system of the Middle Ages and the Early Modern Age. Although the Middle Ages and the Early Modern Age belong to historical times, only few written sources describe burial traditions of this period. Thus, runosongs reflecting these time periods are also invaluable. As noted, the present analysis covers only datable elements and, for example, song-lines describing grief or other emotions may be much older. Although the present approach to the runosong may not always give straight facts, it could still be the best way to say something about the age of the song elements.

I think that runosongs have much to offer to archaeologists studying later time periods. At least burial-related songs provide a human perspective on archaeological material that otherwise does not have a voice. Song narratives give a much wider overview of burials that we may otherwise forget or overlook. This wider picture may raise some questions and give ideas for searching for new archaeological evidence. 


\section{ACKNOWLEDGMENTS}

This research was supported by the European Union through the European Regional Development Fund (Centre of Excellence in Cultural Theory (CECT)) (2008-2015) and by the Estonian Ministry of Education and Research, institutional research funding IUT20-7 "Estonia in Circum-Baltic Space: Archaeology of Economic, Social, and Cultural Processes". I would like to thank my supervisors Heiki Valk and Ester Oras, as well as Maarja Olli, Ragnar Saage, and Valter Lang for their feedback and help during the writing process.

\section{NOTES}

1 I have examined runosongs in the typologically arranged texts of songs at the Estonian Folklore Archives of the Estonian Literary Museum, and the database of Estonian runic songs, http://www.folklore.ee/regilaul, last accessed on February 23, 2017. There might also be some laments among my data if these were catalogued under the songtypes of runosongs. However, if this is the case, it shows that the content of these laments is quite similar to that of runosongs (see also Salve 1993).

2 The typology in this article is based on the one used at the Estonian Folklore Archives.

3 In the cited runosong lines, the verses are divided by a semicolon in the case of parallel verses and by a full stop in other cases.

4 The word kübar means a hat, but in older times it was also used as a synonym for a helmet.

5 The popular mentioning of sikk may also mean a domestic animal, coat, but in songs it occurs as a synonym for a roe.

6 The other possibility is that the Hell (põrgu) is also a prehistoric element and originally not connected with its meaning in Christianity.

\section{ARCHIVAL SOURCES}

\section{Estonian Folklore Archives at the Estonian Literary Museum}

E - manuscript collection of Matthias Johann Eisen

EKS - manuscript collection of the Estonian Literary Society

ERA - manuscript collection of the Estonian Folklore Archives 
EÜS - manuscript collection of the Estonian Students' Society

$\mathrm{H}$ - manuscript collection of Jakob Hurt

Leoke - manuscript collection of Hans and Jaan Leoke

$\mathrm{S}$ - manuscript collection of Samuel Sommer

\section{Estonian National Museum}

ERM Fk - photographic collection

\section{REFERENCES}

Annus, Amar \& Sarv, Mari 2015. Pallimäng ja avanevad hauad sumeri ja eesti rahvalauludes. [The Ball Game and Opening Graves in Sumerian and Estonian Folk Songs.] Akadeemia, No. 12, pp. 2143-2165. Available at http://www.digar.ee/ viewer/et/nlib-digar:266194/231140/page/1, last accessed on February 27, 2017.

Arukask, Madis 2000. "Venna sõjalugu" ja inimmõtlemise muutlikkus: Setu lüroeepiline regilaul kui pideva distantseerumise ja muutumise dokument. [The "Brother's War Tale" and the Mutability of Human Thought: Setu Lyroepical Runo Song as a Documentary Evidence of Constant Distancing and Transformation.] In: Tiiu Jaago \& Ülo Valk (eds.) Kust tulid lood minule... Tartu: Tartu Ülikooli Kirjastus, pp. $57-121$.

Arukask, Madis 2011. Communicating Across the Border: What Burial Laments Can Tell Us About Old Beliefs. Estonian Journal of Archaeology, Vol. 15, No. 2, pp. 130150. http://dx.doi.org/10.3176/arch.2011.2.04.

HCL 2003 = The Chronicle of Henry of Livonia / Henricus Lettus. Translated and with a new introduction and notes by James. A. Brundage. New York: Columbia University Press.

Hiiemäe, Mall 1985. Eesti rahvakalender IV. [Estonian Folk Calendar.] Tallinn: Eesti Raamat.

Jaago, Tiiu 1997. Mis sealt tõuseb, soost sinine, soost sinine, maast punane? Sinise ja punase võimalikust tähendusest regilaulus. [The Possible Meaning of the Parallel Words Blue and Red in Runo Songs.] Mäetagused, Vol. 5, pp. 54-72. DOI: 10.7592/MT1997.05.tiiu.

Jonuks, Tõnno 2005. Archaeology of Religion: Possibilities and Prospects. Estonian Journal of Archaeology, Vol. 9, No. 1, pp. 32-59.

Jonuks, Tõnno 2006. Koerad Eesti asukate viikingiaja maailmapildis. [Dogs in the World-View of the Viking Age.] Mäetagused, Vol. 31, pp. 29-48. DOI: 10.7592/ MT2005.31.jonuks. 
Jonuks, Tõnno 2009. Eesti muinasusund. [Prehistoric Religions in Estonia.] Dissertationes archaeologiae Universitatis Tartuensis 2. Tartu: Tartu University Press. Available at http://www.folklore.ee/ tonno/Jonuks.pdf, last accessed on February 27, 2017.

Jonuks, Tõnno \& Oras, Ester 2012. Sood peidavad ajalugu. [Bogs Hide History.] Eesti Loodus, No. 4, pp. 20-25. Available at http://www.eestiloodus.ee/artikkel4521_4494. html, last accessed on February 27, 2017.

Kahk, Juhan 1980. Nõidumisest ja nõiasõnadest Eestis XVII sajandil. [About the Witchcraft and Spells in the 17th Century Estonia.] Keel ja Kirjandus, No. 11, pp. 673-681. Available at http://www.digar.ee/arhiiv/et/perioodika/34758, last accessed on February 27, 2017.

Kalamees, Aleksander 2007. Eesti rahvamänge. [Estonian Folk Games.] Tallinn: Ajakirjade Kirjastus.

Kama, Pikne 2010. Arheoloogiline vaatepunkt regilaulutüübile "Ema haual”. [Archaeological View of the Runic Song Type "Daughter on Her Mother's Grave”.] Bachelor thesis. Manuscript at the University of Tartu Library. Available at http://www. arheo.ut.ee/theses/BA10_Kama.pdf, last accessed on February 27, 2017.

Kama, Pikne 2012. Arheoloogiline vaatepunkt matuseteemalistele regilaulutü̈̈pidele. [Archaeological View of the Burial Related Types of Estonian Runic Songs.] Master thesis. Manuscript at the University of Tartu Library. Available at http://www. arheo.ut.ee/docs/MA12_Kama.pdf, last accessed on February 27, 2017.

Kemppinen, Iivar 1981. Kadonnut Karjala: Karjalaisen talonpoikaiskulttuurin pääpiirteet. [Lost Karelia: Main Features of Karelian Peasant Culture.] Helsinki: Karjalan Liitto.

Kõuts, Eerik \& Valk, Heinz 1998. Rist ja raud: Põhja-Eesti külaseppade 18. ja 19. sajandil tehtud kalmuriste. [Cross and Iron: Burial Wrought-Iron Crosses from Northern Estonia Made by Village Blacksmiths in the 18th and 19th Centuries.] Tallinn: SE \& JS.

Ksenofontov, Andri 1988. Obiugrilaste kultusehitised. [The Cult Buildings of Ob-Ugric People.] Eesti NSV Teaduste Akadeemia toimetised, Vol. 4, pp. 331-343.

Kulmar, Tarmo 1992a. Eesti muinasusundi hingefenomenoloogiast I: Animism ja preanimism. [On Phenomenology of Soul in Estonian Ancient Religion I: Animism and Preanimism.] Akadeemia, No. 7, pp. 1379-1392. Available at http://www. digar.ee/arhiiv/nlib-digar:101277, last accessed on February 27, 2017.

Kulmar, Tarmo 1992b. Eesti muinasusundi hingefenomenoloogiast II: Hingekujutelmad eesti muinasusundi vanimates kihistustes. [On Phenomenology of Soul in Ancient Estonian Religion II: Soul in the Oldest Strata of Ancient Estonian Religion.] Akadeemia, No. 8, pp. 1601-1620. Available at http://www.digar.ee/arhiiv/nlibdigar:101990, last accessed on February 27, 2017.

Kulmar, Tarmo 1992c. Eesti muinasusundi hingefenomenoloogiast III: Hingekujutlused Eesti kiviaja arheoloogiaaineses. [On Phenomenology of Soul in Ancient Estonian Religion III: Reflections of the Notion of Soul in Stone Age Archaeological Finds in Estonia.] Akadeemia, No. 9, pp. 1870-1887. Available at http://www.digar.ee/ arhiiv/nlib-digar:101279, last accessed on February 27, 2017. 
Kütt, Auli 2007. Maarahva pühade puude ja puistutega seotud käitumisnormid. [Behavioural Norms Related to Sacred Trees and Groves of Estonia.] In: Heiki Valk (ed.) Looduslikud pühapaigad: Väärtused ja kaitse. Tartu: Õpetatud Eesti Seltsi Toimetised, pp. 185-212. Available at https://www.maavald.ee/hiis/yld/ raamat-looduslikud-pyhapaigad, last accessed on February 27, 2017.

Lang, Valter 1996. Muistne Rävala, 2. köide. Muistised, kronoloogia ja maaviljelusliku asustuse kujunemine Loode-Eestis, eriti Pirita jõe alamjooksu piirkonnas. [Prehistoric Rävala, Vol. 2. Antiquities, Chronology and the Establishment of Farming Settlement in North-West Estonia, with Special Reference to the Area on the Lower Reaches of the Pirita River.] Muinasaja Teadus 4. Tallinn: Teaduste Akadeemia Kirjastus.

Lang, Valter 2011. Traceless Death: Missing Burials in Bronze and Iron Age Estonia. Estonian Journal of Archaeology, Vol. 15, No. 2, pp. 109-129. DOI: 10.3176/ arch.2011.2.03.

Laul, Silvia \& Valk, Heiki 2007. Siksälä: A Community at the Frontiers. Iron Age and Medieval. CCC Papers 10. Tartu: University of Tartu.

Lavi, Ain 1999. Põhja-Tartumaa rauatööst muinas- ja varakeskajal. [Iron Working in Northern Tartumaa in Prehistoric Times and in the Early Middle Ages.] Eesti Arheoloogia Ajakiri / Journal of Estonian Archaeology, Vol. 3, No. 1, pp. 35-62.

Lehiste, Ilse \& Ross, Jaan 2001. The Temporal Structure of Estonian Runic Songs. Berlin \& New York: Mouton de Gruyter.

Leimus, Ivar 1996. Numismaatika alused. [Basics of Numismatics.] Tartu: Tartu Ülikooli Ajaloo-Osakond.

Ligi, Priit (comp.) 1993. Vadjapärased kalmed Eestis 9.-16. sajandil. [Votic Graves in Estonia in the 9th-16th Centuries.] Muinasaja teadus 2. Tallinn: Teaduste Akadeemia Kirjastus.

Lintrop, Aado 2001. "Ema haual" lego ja lauluna. ["Daughter on her Mother's Grave" as a Song and Lego Block.] In: Tiiu Jaago \& Mari Sarv (eds.) Regilaul - keel, muusika, poeetika. Tartu: Eesti Kirjandusmuuseum, pp. 299-313.

Loorits, Oskar 1990 [1948]. Eesti rahvausundi maailmavaade. [Worldview in Estonian Folk Religion.] Tallinn: Perioodika.

Losiak, Anna \& Wild, Eva Maria \& Geppert, Wolf Dietrich \& Huber, Matthew Stephen \& Jõeleht, Argo \& Kriiska, Aivar \& Kulkov, Aleksandr \& Paavel, Kristiina \& Pirkovic, Irena \& Plado, Jüri \& Steier, Peter \& Välja, Rudolf \& Wilk, Jakob \& Wisniowski, Tomasz \& Zanetti, Michael 2016. Dating a Small Impact Crater: An Age of Kaali Crater (Estonia) Based on Charcoal Emplaced within Proximal Ejecta. Meteoritics \& Planetary Science, Vol. 51, No. 4, pp. 681-695. DOI: 10.1111/ maps.12616.

Mägi, Marika 2003. Vaimne elu: maailmavaade ja matmiskombed. [The Spiritual World: Beliefs and Burial Rites.] In: Marika Mägi (ed.) Eesti aastal 1200. Tallinn: Argo, pp. 91-106.

Mägi, Marika 2004. The Mortuary House at Lepna on Southern Saaremaa. In: Ülle Tamla (ed.) Arheoloogilised välitööd Eestis / Archaeological Fieldwork in Estonia 2003. Tallinn: Muinsuskaitseamet, pp. 45-60. 
Maldre, Liina 2003. Läänemaa kivikalmete arheozooloogiline aines. [Archaeozoological Data of the Stone Graves in Läänemaa.] In: Mati Mandel. Lä̈̈nemaa 5.-13. sajandi kalmed. Töid ajaloo alalt 5. Tallinn: Eesti Ajaloomuuseum, pp. 263-286.

Mänd, Anu 2004. Pidustused keskaegse Liivimaa linnades 1350-1550. [Festivals in Medieval Livonian Towns in 1350-1550.] Tallinn: Eesti Keele Sihtasutus.

Meri, Lennart 2008. Hõbevalge. Reisikiri suurest paugust, tuulest ja muinasluulest. [Silver White: Travelogue on a Big Bang, the Wind and Ancient Poetry.] Tallinn: Lennart Meri Euroopa Sihtasutus.

Merilai, Arne 2006. Regilaulu ürgsuse müüt: mimesis ja meetrum. [The Myth of the Runo Song's Antiquity: Mimesis and Metrics.] In: Aado Lintrop (ed.) Regilaul esitus ja tõlgendus. Tartu: Eesti Kirjandusmuuseum, pp. 15-18.

Parker Pearson, Mike 2008 [1999]. The Archaeology of Death and Burial. College Station: Texas A\&M University Press.

Paulson, Ivar 1958. Die primitiven Seelenvorstellungen der nordeurasischen Völker. Eine religionsethnographische und religionsphänomenologische Untersuchung. Stockholm: The Ethnographical Museum of Sweden.

Rammo, Riina 2005. Pronksspiraalkaunistused rõivastel Eesti haualeidude põhjal 11.-14. / 15. sajandil. [Bronze Spiral Decorations in Costumes of Estonian 11th14th/15th-Century Grave Finds.] Bachelor thesis. Manuscript at the University of Tartu Library. Available at http://www.arheo.ut.ee/docs/Riina_Rammo_ bakalaureus.pdf, last accessed on February 27, 2017.

Rammo, Riina 2014. Tradition and Transition: The Technology and Usage of PlantFibre Textiles in Estonian Rural Areas in the 11th-17th Centuries. In: S. Lipkin \& K. Vajanto (eds.) Focus on Archaeological Textiles. Monographs of the Archaeological Society of Finland, Vol. 3, pp. 102-115. Available at http://www.sarks.fi/ masf/masf_3/MASF3_08_Rammo.pdf, last accessed on February 27, 2017.

Salve, Kristi 1993. Toone tare: Tähelepanekuid setu surnuitkude žanridevahelisest ja geograafilistest seostest. [The House of Tooni: Notes about Connections between the Genres and Geographical Areas of Setu Laments.] Akadeemia, No. 12, pp. 2605-2621. Available at http://www.digar.ee/arhiiv/nlib-digar:104252, last accessed on February 28, 2017.

Sarv, Mari 2015. Regional Variation in Folkloric Meter: The Case of Estonian Runosong. RMN Newsletter, Vol. 9, pp. 6-17. Available at http://www.helsinki. fi/folkloristiikka/English/RMN/RMN_9_Winter_2014-2015.pdf, last accessed on February 28, 2017.

Schmiedehelm, Marta 1946a. Kaevamisaruanne Jõhvi khk., Kohtla vl., Järve kl., Reinbergi tl. maal. 24. VI 1946. a. - 19.VII 1946.a. [Excavation Report of Jõhvi Parish, Kohtla Commune, Järve Village, Land of Reinbergi Farm. 24. VI 1946-19. VII 1946.] Manuscript at the University of Tartu Library.

Schmiedehelm, Marta 1946b. Kaevamisaruanne Jõhvi khk., Kohtla vl., Järve kl., Reinbergi tl. kivikalmel 3. VII - 17. VII 1946. a. [Excavation Report of Jõhvi Parish, Kohtla Commune, Järve Village, Stone Grave of Reinbergi Farm 3. VII-17. VII 1946.] Manuscript at the University of Tartu Library. 
Selirand, Jüri 1974. Eestlaste matmiskombed varafeodaalsete suhete tärkamise perioodil (11.-13. sajand). [Burial Customs of Estonians during the Early Period of Feudal Relations (11th-13th Centuries).] Tallinn: Eesti Raamat.

Tedre, Ülo 1998. Rahvaluule. [Folklore.] In: Ants Viires \& Elle Vunder (eds.) Eesti rahvakultuur. [Estonian Folk Culture.] Tallinn: Eesti Entsüklopeediakirjastus, pp. 545-587.

Tiirmaa, Udo 1997. Tartu Jaani kiriku alumise matusetsooni kirstudest ja nende etnograafilisest võrdlusmaterjalist. [Coffins in the Lower Burial Zone of Tartu St. John's Church and Their Ethnographical Parallels.] In: Heiki Valk (ed.) Arheoloogilisi uurimusi (1. osa). Tartu Ülikooli Arheoloogia Kabineti toimetised 9. Tartu: Tartu Ülikooli Kirjastus, pp. 71-98.

Torp-Kõivupuu, Marju 2003. Surmakultuuri muutumine ajas: ajaloolise Võrumaa matusekombestiku näitel. [Change of Death Culture Across Time on the Example of Burial Customs of Võrumaa.] Monograph. Tallinna Pedagoogikaülikooli toimetised Humaniora A22. Tallinn: Tallinna Pedagoogikaülikool.

Vainik, Ene 2014. Jumala jälgi ajamas. [Tracing Back the Word jumal ('God').] Mäetagused, Vol. 58, pp. 7-34. DOI:10.7592/MT2014.58.vainik.

Valk, Heiki 1992. Lõuna-Eesti talurahva matmiskombestik ja selle uskumuslikud tagamaad 13.-17/18. sajandil. [The 13th-17/18th Century Village Cemeteries of South Estonia in Folk Tradition and Belief.] Master's thesis. Manuscript at the University of Tartu Library.

Valk, Heiki 1993. Põletusmatustest keskaegses Lõuna-Eestis. [Cremation Burials in Medieval Southern Estonia.] Kleio: Ajaloo Ajakiri, Vol. 7, pp. 5-13.

Valk, Ülo 2000. Regilaul kui kommunikatsioon teispoolsusega: dialoogist nägemusteni. [Runo Song as Communication with the World Beyond the Grave: From Dialogue to Vision.] In: Tiiu Jaago \& Ülo Valk (eds.) Kust tulid lood minule... Tartu: Tartu Ülikooli Kirjastus, pp. 245-276.

Valk, Heiki 2001. Rural Cemeteries of Southern Estonia 1225-1800 AD. 2nd edition. Visby-Tartu: Tartu University Press.

Valk, Heiki 2004. Võre, sõel ja rist: võreripatsid ja nende tähendus. [Lattice, Cross and Sieve: Sieve-Shaped Pendants and Their Meaning.] In: Ivi Tammaru (ed.) Setumaa kogumik 2. Uurimusi Setumaa arheoloogiast, rahvakultuurist, rahvaluulest, ajaloost ja geograafiast. Tallinn: Ajaloo Instituut, pp. 233-313.

Värv, Ellen 2008. Riietumine ja rahvarõivad. [Dressing and Folk Costumes.] In: Ants Viires \& Elle Vunder (eds.) Eesti rahvakultuur. Tallinn: Eesti Entsüklopeediakirjastus, pp. 279-301.

Vassar, Artur 1943. Nurmsi kivikalme Eestis ja tarandkalmete areng. [Nurmsi Stone Grave in Estonia and Genesis of Tarand-Graves.] Diss. (PhD Thesis). Manuscript at the University of Tartu Library. Available at http://www.arheo.ut.ee/docs/ Vassar19431.pdf, last accessed on February 28, 2017.

Vissel, Anu 2004. Lastepärimus muutuvas ühiskonnas. [Children's Lore in the Changing Society.] Ars Musicae Popularis 15. Tartu: Eesti Kirjandusmuuseumi etnomusikoloogia osakond. 
Wessman, Anna 2009. Levänluhta - a Place of Punishment, Sacrifice or Just a Common Cemetery? Fennoscandia archaeologica, Vol. XXVI, pp. 81-105. Available at http:// www.sarks.fi/fa/PDF/FA26_81.pdf, last accessed on February 28, 2017.

Wilson, Eva 2001. 8000 Years of Ornament: An Illustrated Handbook of Motifs. London: British Museum Press.

Pikne Kama defended his doctoral dissertation at the Department of Archaeology, Institute of History and Archaeology, University of Tartu, Estonia, in 2017. He is also head of the Valga Museum.

pikne.kama@gmail.com 